\title{
Exploring the Factor Structure of Environmental Attitudes Measure in a Sample of Indonesian College Students
}

\section{Exploración de la estructura factorial de la Medida de Actitudes Ambientales en una muestra de estudiantes universitarios indonesios}

\author{
Bahrul Hayat ${ }^{1} \underline{\mathrm{ORCID}}$, Rahmat Hidayat ${ }^{2} \underline{\mathrm{ORCID}}$, Muhammad Dwirifqi Kharisma Putra $\underline{\mathrm{ORCID}}$
}

${ }^{1}$ Universitas Islam Negeri (UIN) Syarif Hidayatullah, Jakarta

${ }^{2,3}$ Universitas Gadjah Mada, Yogyakarta

Indonesia

Fecha correspondencia:

Received: February 5, 2020.

Accepted: April 7, 2021.

Forma de citar:

Hayat, B., Hidayat, R., \& Putra, M.D.K. (2021). Exploring the Factor Structure of Environmental Attitudes Measure in a Sample of Indonesian College Students. Rev. CES Psico, 14(1), 112-129.

\section{Open access}

(c) Copyright

Licencia creative commons

Etica de publicaciones

Revisión por pares

Gestión por Open Journal System DOl: http://dx.doi.org/10.21615/ cesp.14.1.9

ISSN: 2011-3080

\section{Abstract}

The purpose of this study was to validate and evaluate the factor structure of the instrument for measuring attitudes towards the environment using factor analysis and multidimensional polytomous Rasch model. Participants in this study were 595 Indonesian university students (293 male and 302 female) with an age range of 18-24 (mean age $=21.01, \mathrm{SD}=1.65)$. The 22-items of Environmental Attitudes Measure were administered using online survey systems. This study generates a three-dimensional factor structure of environmental attitudes in the Indonesian college samples and supports the original scale's theoretical basis. The results of the multidimensional analysis of the polytomous Rasch model show that the psychometric characteristics of this instrument are excellent and have high separation reliability, both for items and person. The findings of this study can be used in future research to examine the interrelationship of environmental attitudes with other variables in the Indonesian sample. Limitations of this study are also discussed.

Keywords: Environmental Attitudes, Factor Analysis, Multidimensional Rasch Model, Validation.

\section{Resumen}

El propósito de este estudio fue validar y evaluar la estructura factorial del instrumento de Medición de Actitudes hacia el Medio Ambiente mediante el análisis factorial y el modelo de Rasch politómico multidimensional. Participaron 595 estudiantes universitarios indonesios (293 hombres y 302 mujeres) con un rango de edad de 18-24 (edad media $=21,01, \mathrm{SD}$ $=1,65)$. Los 22 ítems de la Medida de Actitudes Ambientales se administraron mediante encuestas en línea. Este estudio genera una estructura factorial tridimensional de actitudes ambientales en las muestras univer- 


\section{Sobre los autores:}

1. Ph.D., University of Chicago. MA, University of Pittsburgh. Senior lecturer at the Faculty of Psychology, UIN Syarif Hidayatullah, Jakarta, Indonesia.

2. Ph.D., Tilburg University. MSc, University of Exeter. Senior lecturer at the Faculty of Psychology, Universitas Gadjah Mada, Yogyakarta, Indonesia.

3. Doctoral student at the Faculty of Psychology, Universitas Gadjah Mada, Yogyakarta, Indonesia. MSi, UIN Syarif Hidayatullah Jakarta. sitarias de Indonesia y respalda la base teórica de la escala original. Los resultados del análisis multidimensional del modelo politómico de Rasch muestran que las características psicométricas de este instrumento son excelentes y tienen una alta confiabilidad de separación, tanto por ítems como por persona. Los hallazgos de este estudio se pueden utilizar en investigaciones futuras para examinar la interrelación de las actitudes ambientales con otras variables en la muestra de Indonesia. También se discuten las limitaciones de este estudio.

Palabras clave: Actitudes Ambientales, Análisis Factorial, Modelo Rasch Multidimensional, Validación.

\section{Introduction}

During the last few decades, the relationship between humans and the environment, both the natural and social environment, has become an important issue because it has a long-term impact on forming a person's identity (Wang \& Chiou, 2018). On the one hand, the environment affects humans, and on the other hand, humans also greatly determine the conditions and problems of the environment in which humans live and interact. Social and behavioral sciences such as psychology have a vital role in assessing and addressing environmental issues. Psychology seeks to understand how humans behave toward environmental problems (Oskamp, 2000; Parker \& Prabawa-Sear, 2020).

Although environmental problems have long been the object of study in psychology, the field of environmental psychology as a separate sub-discipline of psychology only became a field of study at the end of the 20th century in line with the environmental issues that have increasingly become a global concern. Environmental psychology is the study of the interaction between humans and their environment and how they use their knowledge to solve environmental problems (Gifford, 2016; Stern, 2000). In brief, environmental psychology is a combination of psychology and environmental sciences. Unfortunately, environmental psychology has not yet received widespread attention in Indonesia, as can be seen from a small number of faculty of psychology offering this course in their curriculum.

In the midst of limited research of environmental psychology in Indonesia, many Indonesian researchers have focused their studies on this field, such as a systematic review of some theories in environmental psychology (Helmi, 1999), some books on environmental psychology (Iskandar, 2013; Jaelani \& Marliani, 2017; Sarwono, 1992), and the exploration of the concept of environmental attitudes across different age groups and contexts (Budijati, 2017; Effendi et al., 2020; Sudarmadi et al., 2001; Sugandini et al., 2018). However, the majority of the abovementioned study focused on a specific sample which is university students.

Environmental issues are essential for the world of higher education to instill attitudes and values for students to protect the environment. Not only limited to the curriculum matters, but the environmental issue is also highly related to the policy on higher education in Talloires Declaration (USLF, 1990) which state that "universities bear profound responsibilities to increase the awareness, knowledge, technologies, and tools to create an environmentally sustainable future". There are four universities in Indonesia that are honored as "green campus", where others try to achieve the same title (Syarif Hidayatullah State Islamic University, 2020; University of Indonesia, 
Pág 114

Some experts define environmental attitude as beliefs that influence a person's behavior or intention to behave and participate in activities or issues related to the environment (Schultz et al., 2004). In line with this definition, the American Psychological Association defines attitudes to the environment as beliefs and values that individuals or communities have concerning nature, ecology, or environmental problems (VandenBos, 2015). The rapid development of research on environmental attitudes cannot be separated from the availability of various instruments measuring environmental attitudes that have been developed (Gifford \& Sussman, (2012).
2016). A decade ago, the University of Indonesia (UI) developed the UI GreenMetric World University Ranking for universities to share their sustainability practices (Tiyarattanachai \& Hollmann, 2016), despite the assessment does not include attitudes or behavior derived from psychological construct.

In contrast to Indonesia, a behavior-based assessment using attitudinal construct was used and explored in a green campus context in some countries (e.g., Coy et al., 2013; Tiyarattanachai \& Hollmann, 2016). The environmental attitude recently has become an essential construct in environmental psychology, as shown by more than half of the publications in this field discussing environmental attitudes (Milfont et al., 2010). Environmental attitude research started as a serious academic activity in the 1970s. The 1980s and early 1990s saw a significant expansion of environmental attitude research and played a significant role in other science disciplines (Gifford \& Sussman, 2012; Rudig, 2001). Some experts define environmental attitude as beliefs that influence a person's behavior or intention to behave and participate in activities or issues related to the environment (Schultz et al., 2004). In line with this definition, the American Psychological Association defines attitudes to the environment as beliefs and values that individuals or communities have concerning nature, ecology, or environmental problems (VandenBos, 2015). The rapid development of research on environmental attitudes cannot be separated from the availability of various instruments measuring environmental attitudes that have been developed (Gifford \& Sussman, 2012).

Several experts have developed several instruments measuring attitude toward the environment, such as the Environmental Attitudes of the University Scale (EAU; Fernandez-Manzanal et al., 2007), Environmental Attitudes Inventory (EAl; Milfont \& Duckitt, 2010), and the Environmental Attitudes instrument developed by Hedlund-de Witt, de Boer and Boersema (2014). The instrument developed by Hedlund-de Witt et al. measures three aspects of attitude: connectedness to nature, willingness to change, and instrumentalism. These aspects were developed as a synthesis of other measuring instruments created previously. The concepts, including the relationship of the self with the natural environment which has been operationalized using different scale (Navarro et al., 2017) and how they adapt to the environmental changes (Milfont, 2012), have not been included in the latest research on environmental attitudes in Indonesia.

Given that environmental attitudes are psychological traits, it is essential to include these three aspects in an instrument measuring attitude and behavior towards the environment in Indonesia. Research findings show that the aspect of connectedness to the nature of Indonesian students is found to be relatively high (Prasetyo et al., 2018). In the context of willingness to change, research results show different findings. A sample of those who feel "unaffected" and "surviving" from environmental problems has a lower attitude compared to a sample of those who feel the "struggling", "adapting", and "willing" groups (Copsey et al., 2013). In terms of instrumentalism, this aspect has become the curriculum content of religious education in Indonesia (Parker \& Prabawa-Sear, 2020).

The dimensionality of the instruments measuring attitude towards the environment has been a long discussion topic by experts, as shown in Milfont (2007). Initially, environmental attitudes were theorized to be unidimensional, a bipolar on a continuum (Dunlap et al., 2000). However, several researchers developed multidimensional instruments with two factors (Ogunbode et al., 2020), three dimensions (Hedlund-de Witt et 
Pág 115

The purpose of this study was to explore the structure of the factors and to evaluate comprehensively psychometric characteristics of the instrument measuring attitudes towards the environment developed by Hedlund-de Witt et al. (2014). Factor analytic methods and multidimensional Rasch analysis were used for this purpose. al., 2014), and 11 generalized environmental attitudes (GEA; Milfont et al., 2010). With a multidimensional factor structure, the interrelationships between dimensions can be modeled and studied, and the relationships with other variables can be explored more deeply (e.g., Kaiser et al., 2007).

In terms of methodology, researchers use various analytical methods for the development and validation of instruments measuring environmental attitudes, such as principal component analysis (Hedlund-de Witt et al., 2014), multi-group confirmatory factor analysis (Milfont et al., 2010), combination of exploratory and confirmatory factor analysis (Navarro et al., 2017), and Rasch analysis (Kaiser et al., 2007; Ogunbode et al., 2020), where the latter uses measurement model perspective. The Rasch model analysis application as a measurement model is the latest development in psychometrics (Suryadi et al., 2020). The Rasch model can model the probability of endorsement of a person for each item (Andrich \& Marais, 2019). Rasch analysis will result in item difficulty and person level of environmental attitudes on the same scale, allowing for direct comparison of item and person (Ogunbode et al., 2020). Both person and item parameters can be ordered and directly interpreted with regard to the item content of the environmental attitudes (Kaiser et al., 2007).

Initially, the Rasch model assumes that the instrument being analyzed has a single dimension (unidimensional). However, along with the need to analyze instruments with multidimensional factor structures, a multidimensional Rasch analysis has been developed (Adams et al., 1997; Rahayu et al., 2021). Although it has been developed for quite a long time and used in analyzing environmental attitude measures (see Kaiser et al., 2007), an application of the multidimensional Rasch analysis in environmental research in Indonesia has not been found. The unidimensional Rasch model was used to analyze the Campbellian measure of pro-environmental attitudes in Nigerian samples (Ogunbode et al., 2020) and provides a more detailed item-level interpretation. The multidimensional Rasch model was utilized to analyze behavior-based environmental attitudes and found that six specific factors were statistically more appropriate than one general scale (Kaiser et al., 2007). Since our study theoretically measures multidimensional construct, we employed a multidimensional Rasch model to analyze the study's data.

To this end, the purpose of this study was to explore the structure of the factors and to evaluate comprehensively psychometric characteristics of the instrument measuring attitudes towards the environment developed by Hedlund-de Witt et al. (2014). Factor analytic methods and multidimensional Rasch analysis were used for this purpose. This research provides novelty in terms of theoretical aspect by finding the dimensionality structure of environmental attitudes in the Indonesian sample and methodological aspect by utilizing the advantages of the advanced psychometric methods such as multidimensional Rasch model.

\section{Methods}

\section{Sample}

This study's sample was 595 students of public and private universities in Indonesia, aged 18 to 24 years (mean age $=21.01 ; \mathrm{SD}=1.65$ ). The sample consisted of 293 male and 302 female. Table 1 provides the demographic characteristics of the sample. Data were collected using online administration and recruited by email invitation. All respondents of the study had filled in an informed consent containing 
their agreement to be research participants and had known that the research being conducted would be published while maintaining the confidentiality of the respondent's identity. Respondents were also informed that participation was voluntary without any compensation and had full rights to reject and stop participating at any time after the data collection begin. This study was conducted under the standards and ethical guidance from the relevant institutional boards (Decree No. 475a/2017).

Table 1. Demographic characteristics of respondents

\begin{tabular}{lcc}
\hline Variable & Frequency & Percentage \\
\hline Gender & & \\
\hline Male & 293 & 49.24 \\
\hline Female & 302 & 50.76 \\
\hline Age & & \\
\hline 18 & 48 & 8.06 \\
\hline 19 & 67 & 11.26 \\
\hline 20 & 127 & 21.34 \\
\hline 21 & 109 & 18.31 \\
\hline 22 & 115 & 19.32 \\
\hline 23 & 96 & 16.13 \\
\hline 24 & 33 & 5.54 \\
\hline University & & \\
\hline Public & 344 & 57.81 \\
\hline Private & 251 & 42.19 \\
\hline
\end{tabular}

\section{Environmental Attitudes Measure}

Hedlund-de Witt, De Boer, and Boersema (2014) define environmental attitude as "the collection of beliefs, affect, and behavioral intentions, a person holds regarding environmentally related activities or issues". Based on exploratory approach, Hedlund-de Witt et al. identified three aspects of attitude towards the environment, namely: (1) connectedness to nature (CTN), that is the attitude and feelings of someone who is always connected with nature and cares for nature. This is related to the lifestyle of someone who is always close to nature; (2) willingness to change (WTC), person's desire to change conditions socially that can improve the environment either through government policies or individual behavior; and (3) instrumentalism (INS), namely person's belief about the instrumental role of external factors in solving environmental problems. These external factors are in the form of the power of science, technology, and economy. Therefore, the person does not feel an individual obligation to change and improve the environment. Using these three aspects as a reference, Hedlund-de Witt et al. (2014) developed an Environmental Attitudes instrument containing 22 items. Of the 22 items, nine items are theorized to measure the aspect of connectedness to nature (items 1-9), six items measure the aspect of willingness to change (items 10-15), and the other seven items measure the aspect of instrumentalism (items 16-22). Item wording for the environmental attitude measures can be found on Appendix A.

For this study, the original items in English developed by Hedlund-de Witt et al. (2014) were translated into Indonesian by authors and reviewed by two faculty members of the Faculty of Psychology UIN Syarif Hidayatullah Jakarta. In the original version, 
Pág 117

The Rasch model was initially developed for dichotomous data analysis. This model allows the researcher to perform item calibration and person measurements on the same scale. When this is done, modeling the prediction of a person's response to an item can be known (Andrich \& Marais, 2019). The person and item parameters in the Rasch model are expressed on a logit scale. Although mathematically simple, this model has various unique characteristics that meet fundamental measurement principles (Mair, 2018). the instrument uses a 7-point Likert scale format, and for this study, the researchers modified it to 4-points (strongly disagree, disagree, agree, and strongly agree). This modification is carried out by considering the use of analysis based on the Rasch model, which requires that each option be responded to by a minimum of 10 respondents to avoid large infit and outfit values for each option and to avoid disordered threshold (Linacre, 1999; 2010).

\section{Factor Analysis}

Factor analysis is a statistical method for analyzing the factor structure and pattern of factor relationships. There are two types of factor analysis: Exploratory Factor Analysis (EFA) and Confirmatory Factor Analysis (CFA). EFA is used to explore the factor structure of a measurement instrument to be further confirmed by CFA (Wang \& Wang, 2020). The EFA procedure begins with the extraction, rotation, and naming of the factors (Brown, 2015). Considering that the instrument used in this study contains three factors (see Hedlund-de Witt et al., 2014), we tested with EFA to check if there was a change in the factor structure using the Indonesian sample. The researchers employed the IBM SPSS 22 program for EFA.

Based on the EFA analysis findings, the researchers then confirmed the instrument's factor structure using the CFA. The criteria used for the fit of the model were RMSEA $<0.05, C F \mid>0.90, T L I>0.90$, and $S R M R<0.08$, which are general criteria suggested by various literature (e.g., Hu \& Bentler, 1999; Wang \& Wang, 2020). After we found that the model fitted the data, the CFA analysis results were then used for the application of the multidimensional Rasch model. EFA and CFA provide important information about the instrument's dimensionality before applying the Rasch model analysis (Rahayu et al., 2021). For CFA, we employed the MPLUS 8.4 program with a robust maximum likelihood estimation method.

\section{Multidimensional Rasch Model}

From the beginning of the 20th century until now, measurement in the field of psychology is still dominated by the classical psychometric approach, in which the quality of the instrument is carried out by looking at the validity and reliability, which is highly dependent on the sample of people used for this purpose. This psychometric analysis does not provide a basis for ideal measurement principles; among other things, the resulting unit of measurement does not have the same interval (interval scale). The score generated from this measuring tool is not linear with the psychological attributes (trait) being measured. In addition, the interpretation of normative scores from psychological measuring instruments using the classical psychometric approach is very vulnerable to a sample of people used as a reference (norm) group. This normative score does not allow a substantive interpretation of the instrument; namely, the meaning of the score obtained associated with the psychological attributes (traits) measured (see Choppin, 1982; Rasch, 1960; Wright \& Stone, 1979). The Rasch model (Rasch, 1960) was developed to overcome these weaknesses.

The Rasch model was initially developed for dichotomous data analysis. This model allows the researcher to perform item calibration and person measurements on the same scale. When this is done, modeling the prediction of a person's response to an item can be known (Andrich \& Marais, 2019). The person and item parameters in the Rasch model are expressed on a logit scale. Although mathematically simple, this model has various unique characteristics that meet fundamental measurement principles (Mair, 2018). Various variants of the Rasch model have been developed to accomodate various response formats of instruments, including the Rasch Model for 
Pág 118

The CFA results with a sample of Indonesian students confirm the Environmental Attitudes instrument's multidimensional factor structure. Although researchers are still debating Environmental Attitudes' dimensionality, this finding is in line with the hypothesized model's theoretical basis in the original version of The Environmental Attitudes instrument (Hedlund-de Witt et al., 2014). At the same time, these findings complement the research evidence on multidimensionality measurement of environmental attitudes that have been carried out previously (e.g., Kaiser et al., 2007; Milfont et al., 2010). analyzing polytomous data. Rating Scale Model (RSM; Andrich, 1978) and the Partial Credit Model (PCM; Masters, 1982) are the most popular Rasch models for analyzing polytomous data. Because all items in the Environmental Attitudes are in the form of a Likert scale, the Polytomous Rasch Model (PRM) was used in this study.

In the Polytomous Rasch model, the Likert scale category threshold is included in the item estimation process. A threshold is the point of transition of a person's response from one category to the next on a Likert scale. The number of thresholds is equal to the number of categories ( $k$ ) minus one (Wright \& Masters, 1982). PRM is used to estimate a person's probability of choosing a particular response category in the rating scale when a person's ability regarding the construct being measured and the item parameters are known. In this study, each item has four response options on an ordinal scale. There are three thresholds with these four options (categories), namely options 2 to 1 , options 3 to 2, and options 4 to 3 (de Ayala, 2009).

Considering that the Rasch model assumes unidimensionality, while the construct of environmental attitudes is theorized to be multidimensional, this study used a multidimensional random coefficients multinomial logit model (MRCMLM; Adams et al., 1997). The item parameters are estimated using the marginal maximum likelihood with the Markov Chain Monte Carlo (MCMC) approximation method. Whereas all students' level of environmental attitudes will be expressed in the form of weighted likelihood estimates (WLE; Warm, 1989). Both item and person parameters are represented in the logit scale. To determine the appropriate parameterization, a comparison was made between the Multidimensional PCM and RSM models using the Akaike Information Criterion (AIC), where the smallest AIC shows the preferable model (Adams et al., 2020; Briggs \& Wilson, 2003). Multidimensional Rasch analysis was estimated using the ConQuest 5.13 (Adams et al., 2020) software developed by the Australian Council for Educational Research (ACER).

\section{Results}

\section{Exploratory Factor Analysis (EFA)}

The application of EFA is carried out to explore the factor structure of Environmental Attitudes instrument. Factor extraction with principal axis factoring was carried out at this stage, and factor rotation was conducted using direct oblimin. This method's choice is based on prior knowledge that factors of the Environmental Attitudes instrument can correlate with one another. The criteria used to determine the number of factors is the Kaiser criterion (Brown, 2015), where the eigenvalue must be above 1.00. The EFA results show that the Environmental Attitudes instrument consists of 3 factors with eigenvalues above 1 . These three factors produce a $50.81 \%$ variance.

This finding suggests that although the number of dimensions produced in the Indonesian college sample follows the authors' theoretical framework, the factor structure differs at the item level (See Table 2). The difference lies in two items, namely item 17 and item 21. Item 17 and item 21 were originally theorized by Hedlund-de Witt et al. (2014) to measure the instrumentalism aspect. However, this study's finding showed that the two items measure an aspect of the connectedness to nature. Therefore, further analysis was carried out to confirm the factor structure using the CFA. 
Table 2. Factor structures of environmental attitude measure

\begin{tabular}{|c|c|c|c|c|c|c|c|c|c|}
\hline \multirow{2}{*}{ Item } & \multicolumn{3}{|c|}{ Hedlund-de Witt et al. (2014) PCA } & \multicolumn{3}{|c|}{ This study (EFA) } & \multicolumn{3}{|c|}{ This study (CFA) } \\
\hline & Factor 1 & Factor 2 & Factor 3 & Factor 1 & Factor 2 & Factor 3 & Factor 1 & Factor 2 & Factor 3 \\
\hline Item 1 & 0.81 & & & 0.53 & & & 0.54 & & \\
\hline Item 2 & -0.69 & & & -0.54 & & & -0.57 & & \\
\hline Item 3 & 0.66 & & & 0.48 & & & 0.51 & & \\
\hline Item 4 & 0.59 & & & 0.44 & & & 0.42 & & \\
\hline Item 5 & -0.52 & & & -0.71 & & & -0.70 & & \\
\hline Item 6 & 0.51 & & & 0.58 & & & 0.55 & & \\
\hline Item 7 & 0.50 & & & 0.69 & & & 0.65 & & \\
\hline Item 8 & -0.45 & & & -0.63 & & & -0.64 & & \\
\hline Item 9 & 0.33 & & & 0.63 & & & 0.63 & & \\
\hline Item 10 & & 0.70 & & & 0.52 & & & 0.53 & \\
\hline Item 11 & & 0.69 & & & 0.67 & & & 0.68 & \\
\hline Item 12 & & 0.66 & & & 0.54 & & & 0.53 & \\
\hline Item 13 & & 0.62 & & & 0.80 & & & 0.79 & \\
\hline Item 14 & & 0.53 & & & 0.82 & & & 0.82 & \\
\hline Item 15 & & -0.50 & & & -0.65 & & & -0.66 & \\
\hline Item 16 & & & 0.68 & & & 0.76 & & & 0.75 \\
\hline Item 17 & & & 0.65 & -0.48 & & & -0.48 & & \\
\hline Item 18 & & & 0.61 & & & 0.82 & & & 0.83 \\
\hline Item 19 & & & 0.58 & & & 0.74 & & & 0.74 \\
\hline Item 20 & & & 0.56 & & & 0.73 & & & 0.75 \\
\hline Item 21 & & & 0.43 & 0.61 & & & 0.64 & & \\
\hline Item 22 & & & 0.43 & & & 0.78 & & & 0.76 \\
\hline \multicolumn{10}{|c|}{ Factor correlations } \\
\hline Factor 1 & - & & & - & & & - & & \\
\hline Factor 2 & 0.54 & - & & 0.32 & - & & 0.42 & - & \\
\hline Factor 3 & -0.32 & -0.31 & - & -0.41 & -0.31 & - & -0.49 & -0.33 & - \\
\hline
\end{tabular}

Note. Factor 1: Connectedness to nature, Factor 2: Willingness to change, Factor 3: Instrumentalism.

\section{Confirmatory Factor Analysis (CFA)}

The result of CFA showed that the 3 -factor model fits the data with a value of $=603.60(206), p=0.000$, RMSEA $=0.057$ (90\% Cl 0.052-0.062), CFI $=0.917$, dan TLI $=0.907$. These findings indicate that the factor structure of the Environmental Attitudes in the form of a 3-factor model obtained through EFA fits the data. All items were statistically significant, with factor loadings between 0.425 and 0.828 . The R-square value for all items was also significant $(p<0.01)$. The CFA results also confirm the dimension change of items 17 and 21 . The item was originally designed to measure the instrumentalism aspect, and the CFA showed that the items measure an aspect of connectedness to nature. We also found that these three factors were correlated with a correlation range of -0.332 to -0.489 (See Table 2). 


\section{Rasch Analysis}

Model Comparison

In line with the CFA analysis results, which confirmed that the instrument has a multidimensional structure, the multidimensional model was used for Rasch analysis (See Table 2). However, there is no goodness-of-fit index for multidimensional Rasch analysis. Consequently, we used information criteria to compare RSM or PCM of the Rasch model to analyze Likert scale data (Briggs \& Wilson, 2003). The comparative analysis between the two models was used to determine which model is appropriate to analyze the Environmental Attitudes instrument.

Table 3. Model comparison results

\begin{tabular}{cccc}
\hline Model & Final Deviance & AIC & Parameter \\
\hline Multidimensional PCM & 27023.64 & 27167.64 & 72 \\
\hline Multidimensional RSM & 27245.74 & 27305.74 & 30 \\
\hline
\end{tabular}

As shown in Table 3, Multidimensional PCM has a lower Akaike Information Criterion (AIC) value than multidimensional RSM. This means that the Multidimensional PCM of the Rasch model is more appropriate for analyzing the Environmental Attitude instrument. Under this model, each item in the Environmental Attitudes instrument has its threshold structure for each item non-uniformly so that the results of the analysis for the item and person parameters can be interpreted more precisely.

\section{Item Difficulty and Step Parameter}

Table 4 contains the psychometric characteristics of Environmental Attitudes items resulting from the Multidimensional PCM Rasch analysis, which includes the item difficulty on a logit scale, fit statistics, and step parameters. As shown from the table, all items fit with the Rasch model with infit and outfit values within acceptable limits (0.5-1.5) (Linacre, 2002). The item difficulty level is in a symmetrical value range with the lowest value of -0.926 and the highest of 0.978 . Item number 20 , which reads "In these economically difficult times, environmental requirements should not become obstacles to economic growth" is the most difficult item to be endorsed by respondents with a value of 0.978 logit. On the other hand, item number 22, which reads, "I don't feel responsible for contributing to solving the environmental crisis" with a value of -0.926 logit is the easiest item for respondents to agree. Given that this item was reversed, it can be interpreted that this item is the easiest to answer "strongly disagree". The Rasch analysis results show that all items fit the Rasch model and are valid for measuring environmental attitudes.

In applying the Likert scale, it is assumed conceptually that the distances between categories are the same. However, in practice, the distances between categories are not always the same. Therefore, a diagnostic analysis was performed to evaluate how well the instrument's four categories form an interpretable measure. From the analysis results, the researchers found that the value of each category's step parameter for all items of the Environmental Attitude instrument increases from low to high. None of the step parameters is disordered. The unordered step parameter indicates the occurrence of a disordered threshold (Linacre, 1999; 2010), and further collapsing categories is not necessary. Considering that the entire thresholds are increasing, it can be concluded that the four-point Likert scale for the Environmental Attitude instrument functions well in this study. 
Table 4. Rasch analysis results: item measure, fit statistics, and threshold.

\begin{tabular}{|c|c|c|c|c|c|c|c|}
\hline \multirow{2}{*}{ Aspects } & \multirow{2}{*}{ Item } & \multirow{2}{*}{ Measure } & \multirow{2}{*}{ Infit } & \multirow{2}{*}{ Outfit } & \multicolumn{3}{|c|}{ Threshold } \\
\hline & & & & & Step 1 & Step 2 & Step 3 \\
\hline \multirow{11}{*}{$\begin{array}{l}\text { Connectedness } \\
\text { to Nature }\end{array}$} & Item 1 & -0.672 & 1.02 & 0.99 & -1.757 & -0.370 & 2.127 \\
\hline & Item 2 & -0.318 & 0.97 & 0.97 & -2.285 & 0.002 & 2.283 \\
\hline & Item 3 & -0.367 & 1.05 & 1.07 & -1.786 & -0.475 & 2.261 \\
\hline & Item 4 & 0.745 & 1.28 & 1.32 & -1.591 & -0.047 & 1.638 \\
\hline & Item 5 & 0.003 & 0.86 & 0.85 & -1.545 & -0.108 & 1.654 \\
\hline & Item 6 & 0.058 & 1.08 & 1.09 & -1.704 & -0.110 & 1.814 \\
\hline & Item 7 & 0.129 & 0.94 & 0.95 & -1.544 & -0.261 & 1.806 \\
\hline & Item 8 & 0.698 & 0.99 & 0.99 & -1.805 & 0.046 & 1.759 \\
\hline & Item 9 & -0.290 & 0.95 & 0.95 & -1.585 & -0.164 & 1.749 \\
\hline & Item 17 & -0.065 & 1.20 & 1.33 & -1.200 & -0.212 & 1.412 \\
\hline & Item 21 & 0.080 & 0.92 & 0.92 & -2.118 & 0.040 & 2.078 \\
\hline \multirow{6}{*}{$\begin{array}{l}\text { Willingness to } \\
\text { Change }\end{array}$} & Item 10 & -0.672 & 1.17 & 1.13 & -1.659 & -0.630 & 2.289 \\
\hline & Item 11 & 0.154 & 0.99 & 1.02 & -1.555 & -0.554 & 2.109 \\
\hline & Item 12 & 0.212 & 1.25 & 1.34 & -1.340 & -0.653 & 1.993 \\
\hline & Item 13 & 0.162 & 0.86 & 0.82 & -1.551 & -0.393 & 1.944 \\
\hline & Item 14 & -0.110 & 0.83 & 0.77 & -1.382 & -0.637 & 2.019 \\
\hline & Item 15 & 0.254 & 1.06 & 1.09 & -1.800 & -0.259 & 2.059 \\
\hline \multirow{5}{*}{ Instrumentalism } & Item 16 & -0.263 & 0.98 & 0.96 & -2.795 & 0.021 & 2.774 \\
\hline & Item 18 & 0.860 & 0.89 & 0.84 & -2.068 & 0.090 & 1.978 \\
\hline & Item 19 & -0.649 & 1.03 & 0.91 & -2.468 & 0.096 & 2.372 \\
\hline & Item 20 & 0.978 & 1.10 & 1.08 & -2.136 & -0.255 & 2.391 \\
\hline & Item 22 & -0.926 & 0.99 & 0.86 & -2.610 & -0.041 & 2.650 \\
\hline
\end{tabular}

Separation reliability indices

In the Rasch model, reliability is not the same as in the classical psychometric approach. Rasch analysis estimate reliability values for both persons and items (Wright \& Masters, 1982). Person reliability in the form of weighted likelihood estimates (WLE) indicates how well an instrument can distinguish individuals within a range of scales in terms of the measured constructs (Adams, 2005). In other words, WLE reliability describes how effective and reliable the instruments of Environmental Attitudes are in measuring the differences among a person's environmental attitudes. The analysis shows that the value of WLE reliability is 0.844 for the connectedness to nature dimension, 0.757 for the willingness to change dimension, and 0.800 for the instrumentalism dimension. In parallel, this study's item separation reliability is 0.977 , which implies that the person sample is large enough to confirm the instrument's item difficulty hierarchy. These findings indicate that the reliability of the Environmental Attitudes instrument is excellent.

\section{Wright Map and person measure}

In addition to information about item parameter estimation, Rasch analysis also provides a Wright Map showing the relationship between the person's latent trait level and the estimated level of item difficulty on the same logit scale (Wilson \& Draney, 2002). The Wright Map of the Environmental Attitude instrument using the sample of this study can be seen in Figure 2 below. 


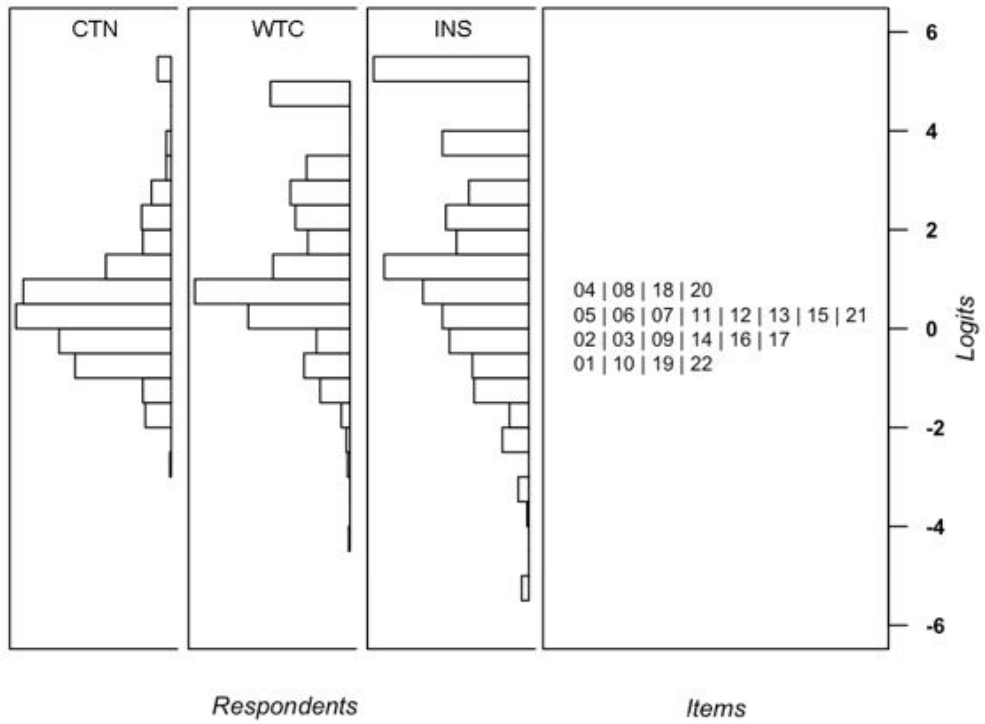

Figure 2. Wright Map of environmental attitudes measures

From Figure 2, we can see that the average latent trait level of persons for the dimensions of connectedness to nature (CTN), willingness to change (WTC), and instrumentalism (INS) has a positive value, with values of $0.389,1.416$, and 1.590 logits, respectively. The person levels of environmental attitude for each dimension are higher than the mean of item difficulty level, which equals zero for each aspect. In other words, in all aspects, the sample persons under this study have a very positive attitude towards the environment. The instrumentalism aspect is the aspect with the highest value for the persons. The Indonesian sample tends to have a higher attitude for the instrumental aspect than two other aspects.

Besides, the mean of the person's trait level for each aspect was found to increase from low (CTN) to high (INS). This shows that the CTN aspect is the lowest aspect and the INS aspect is the highest aspect. This means that the sample of Indonesian college students tends to have high environmental instrumentalism compared to the other two aspects. Furthermore, we found that the item difficulty range was smaller than the person measure range. This happens in all three aspects. This is because this instrument does not have items that measure extreme attitudes, both for low and high altitudes. Therefore, adding items needs to be done by including items that measure attitudes and behaviors that are theoretically easier and harder to agree on. Thus, the scope of attitudes measured by this instrument will cover a broader continuum so that the instrument can more accurately measure environmental attitudes and implement the best test design (Wright \& Stone, 1979).

\section{Discussion}

This study aimed to explore the factor structure and evaluate the psychometric characteristics of the 3-factor Environmental Attitudes instrument developed by Hedlund-de Witt et al. (2014). This study finds that the three factors theorized by the developer also apply to the Indonesian sample. However, based on the EFA results, there are differences in 2 items (item 17 and item 21), which were theorized initially to measure instrumentalism; in the Indonesian sample, it was found that these two items measure an aspect of the connectedness to nature. This finding is very interesting where item 17, which reads "By mastering nature, the human being can find freedom", 
Considering that the Rasch model assumes unidimensionality, while the construct of environmental attitudes is theorized to be multidimensional, this study used a multidimensional random coefficients multinomial logit model (MRCMLM; Adams et al., 1997). belongs to the aspect of the connectedness to nature. For Indonesian students, this item's content and substance seem to measure the connectedness to nature aspect more than the instrumentalism aspect.

Meanwhile, Item 21, which reads "I think animal rights are nonsense", goes into the aspect of connectedness to nature. It is most likely that the item's substance is closely related to Indonesian students' culture and knowledge. The concept of animal rights, a theme in environmental attitudes, is not well understood and is not common knowledge for most Indonesians. The concept of animal rights is understood only by a group of animal welfare activists (Resolute, 2016). This finding may also be related to the cultural and religious context, where all of our samples are Muslims. The concept of nature in Islamic teachings includes animals as part of nature, so that in Islamic law (sharia), loving animals is the obligation of a Muslim (Abbas, 2017). We suspect that respondents answered Item 21 based on religious beliefs, not considerations of animal rights.

The CFA results with a sample of Indonesian students confirm the Environmental Attitudes instrument's multidimensional factor structure. Although researchers are still debating Environmental Attitudes' dimensionality, this finding is in line with the hypothesized model's theoretical basis in the original version of The Environmental Attitudes instrument (Hedlund-de Witt et al., 2014). At the same time, these findings complement the research evidence on multidimensionality measurement of environmental attitudes that have been carried out previously (e.g., Kaiser et al., 2007; Milfont et al., 2010). This finding allows each aspect to be analyzed separately in a theoretical context and relates it to other relevant variables (Hedlund-de Witt et al., 2014), such as the research focusing on the aspect of connectedness to nature (e.g., Dutcher et al., 2007; Navarro et al., 2017).

Other examples are studies by Prasetyo et al. (2018), which show a high attitude of Indonesian students regarding connectedness to nature, and research by Copsey et al. (2013), which shows a high level of willingness to change of the Indonesian sample. The high willingness to change occurs due to the Indonesian sample's attitude to be part of the effort to change environmental conditions. The environmental instrumentalism aspect is interesting to study since it is part of the religious education curriculum (Parker \& Prabawa-Sear, 2020). These three aspects need to be examined separately according to contexts. The instrument of Environmental Attitudes used in this study provides an alternative by combining these three aspects of environmental attitudes in one instrument. At the same time, the analysis can be carried out separately for each environmental attitude aspect.

This study is the first to apply multidimensional Rasch analysis to an instrument measuring environmental attitudes in Indonesia. Previous studies used Rasch analysis separately for each dimension of an instrument with a multidimensional factor structure such as the application of Rasch analysis to the measurement instrument for environmental attitudes in Nigeria (Ogunbode et al., 2020), which analyzed separately each dimension of the instrument consisting of two dimensions. Another study used multidimensional Rasch analysis to compare one general factor and six-specific factor of behavior-based environmental attitudes assessment (Kaiser et al., 2007). This study provides an overview of the multidimensional Rasch model's direct application to the Indonesian sample data. This study found that the psychometric characteristics of the Environmental Attitudes instrument were excellent. All items fit the Rasch model. These findings provide evidence about the validity and reliability of 
Pág 124

From the results of this study, we conclude that the 3-factor multidimensional factor structure of Environmental Attitudes instrument is proven to be appropriate for use in the Indonesian sample. The Environmental Attitudes instrument has excellent psychometric characteristics, in terms of construct validity, separation reliability, and measurement objectivity, so that researchers can use the instrument in relevant future research. the instrument measuring attitudes towards the environment. Besides, the format modification by changing the 7-point Likert scale to 4-point was proven to function properly, and none of the items had a disordered threshold. The item options are well understood and do not confuse respondents.

In terms of correlations between latent factors, we found a consistent pattern of correlations between factors using EFA, CFA, and original correlation pattern (see Hedlund-de Witt et al., 2014), where CTN and WTC negatively correlated with instrumentalism. This means that the higher the person's attitude of connectedness to nature, the higher the attitude of willingness to change and lower the instrumentalism. Likewise, the high attitude of willingness to change is related to the lower attitude of instrumentalism. This result in line with the initial finding that instrumentalism is a negative aspect, which means that other aspects negatively correlate with instrumentalism (Hedlund-de Witt et al., 2014). Theoretically, this supports the findings of environmental instrumentalism in Indonesian students, which is an essential aspect to explore (Parker \& Prabawa-Sear, 2020).

This study has several limitations. The first limitation relates to the sample used. This study's sample came from Banten province in Indonesia, which did not represent the other 33 provinces. The Banten is a neighboring province of Jakarta as the national capital. It is interesting to know how the sample's environmental attitudes from inland areas with different traditional and cultural contexts have different environmental characteristics. Comparing the attitudes of connectedness to nature, willingness to change, and instrumentalism from a sample of persons in big cities with a rural people sample is also interesting. It is interesting to study persons' environmental attitudes from inland areas having a unique cultural context. It is also interesting to compare each aspect of attitudes toward the environment (connectedness to nature, willingness to change, and instrumentalism) from a sample of large urban communities with a sample of rural communities.

The second limitation is related to the instrument used. Although the Environmental Attitudes instrument used in this study includes aspects of connectedness to nature, willingness to change, and instrumentalism, this study does not include other aspects that have been researched and developed by other researchers in Indonesia. Future researches may compare various instruments with different theorized aspects of attitude towards the environment and study their relationships with other psychological factors (for example, personality traits). Lastly, the third limitation is related to our study samples. Our study employed only college students with a specific age group. Although we understand the invariant property of the Rasch model, we encourage other researchers to examine the possibility of measurement bias across different groups. Additionally, our sample also not a representative of the general respondents from specific area of our study. Thus, future research can overcome this issues to result in more reliable diagnostic assessment tools across age, education and more diversed sample.

\section{Conclusion}

From the results of this study, we conclude that the 3-factor multidimensional factor structure of Environmental Attitudes instrument is proven to be appropriate for use in the Indonesian sample. The Environmental Attitudes instrument has excellent psychometric characteristics, in terms of construct validity, separation reliability, and measurement objectivity, so that researchers can use the instrument in relevant future research. This research contributes to the development of environmental 
psychology research in Indonesia. Methodologically, applying the multidimensional Rasch model in this study also contributes to developing psychometric research in Indonesia.

\section{Acknowledgements}

We declared no potential conflicts of interest with respect to the research, authorship and/or publication of this article.

We received no financial support for the research, authorship and/or publication of this article.

\section{References}

Abbas, A. S. (2017). Syari'at perlindungan dan pemeliharaan alam. Jurnal HIMMAH, 1(1), 4-22.

Adams, R., Cloney, D., Wu, M., Osses, A., \& Vista, A. (2020). ConQuest manual. Australian Council for Educational Research.

Adams, R. J. (2005). Reliability as a measurement design effect. Studies in Educational Evaluation, 31(2-3), 162-172. https://doi.org/10.1016/i.stueduc.2005.05.008

Adams, R. J., Wilson, M., \& Wang, W. (1997). The multidimensional random coefficients multinomial logit model. Applied Psychological Measurement, 21(1), 1-23. https://doi.org/10.1177/0146621697211001

Andrich, D. (1978). A rating formulation for ordered response categories. Psychometrika, 43(4), 561-573. https://doi.org/10.1007/BF02293814

Andrich, D., \& Marais, I. (2019). A course in Rasch measurement theory: Measuring in the educational, social, and health sciences. Springer Nature Singapore Pte Ltd.

Briggs, D. C., \& Wilson, M. (2003). An introduction to multidimensional measurement using Rasch models. Journal of Applied Measurement, 4(1), 87-100.

Brown, T. A. (2015). Confirmatory factor analysis for applied research (2nd ed.). Guilford Press.

Budijati, S. M. (2017). The influence of environmental values and attitude on student's intentions to participate in take-back programs. Asia-Pacific Journal of Science and Technology, 22(1), 42-51. https://doi.org/10.14456/apst.2017.24

Choppin, B. (1982). The use of latent trait models in the measurement of cognitive abilities and skills. In D. Spearritt (Ed.), The Improvement of Measurement in Education and Psychology (pp. 41-63). Australian Council for Educational Research.

Copsey, T., Dalimunthe, S., Hoitjink, L., \& Stoll, N. (2013). How the people of Indonesia live with climate change and what communication can do. BBC Media Action.

Coy, A. E., Farrell, A. K., Gilson, K. P., Davis, J. L., \& Le, B. (2013). Commitment to the environment and student support for "green" campus initiatives. Journal of Environmental Studies and Sciences, 3(1), 49-55. https://doi.org/10.1007/s13412012-0100-1

de Ayala, R. J. (2009). The theory and practice of item response theory. Guilford Press.

Dunlap, R. E., Van Liere, K. D., Mertig, A., \& Jones, R. E. (2000). Measuring endorsement of the new ecological paradigm: A revised NEP scale. Journal of Social Issues, 56(3), 425-442. https://doi.org/10.1111//0022-4537.00176

Dutcher, D. D., Finley, J. C., Luloff, A. E., \& Johnson, J. B. (2007). Connectivity with nature as a measure of environmental values. Environment and Behavior, 39(4), 474-493. https://doi.org/10.1177/0013916506298794

Effendi, M. I., Sugandini, D., Sukarno, A., \& Kundarto, M. (2020). The antecedent of environmental attitude. Journal of Environmental Management and Tourism, 11(6), 1581-1587. https://doi.org/10.14505/jemt.v11.6(46).28 
Fernandez-Manzanal, R., Rodriguez-Barreiro, L., \& Carrasquer, J. (2007). Evaluation of environmental attitudes: Analysis and results of a scale applied to university students. Science Education, 91(6), 988-1009. https://doi.org/10.1002/sce.20218

Gifford, R. (2016). Introduction: Environmental psychology and its methods. In R. Gifford (Ed.), Research methods for environmental psychology (pp. 1-8). John Wiley \& Sons, Ltd.

Gifford, R., \& Sussman, R. (2012). Environmental attitudes. In S. D. Clayton (Ed.), Oxford library of psychology. The Oxford handbook of environmental and conservation psychology (p. 65-80). Oxford University Press.

Helmi, A. F. (1999). Beberapa teori psikologi lingkungan. Buletin Psikologi, 7(2), 7-19.

Hedlund-de Witt, A. H., de Boer, J., \& Boersema, J. J. (2014). Exploring inner and outer worlds: A quantitative study of worldviews, environmental attitudes, and sustainable lifestyles. Journal of Environmental Psychology, 37, 40-54. https://doi. org/10.1016/i.jenvp.2013.11.005

Hu, L., \& Bentler, P. M. (1999). Cutoff criteria in covariance structure analysis: Conventional criteria versus new alternatives. Structural Equation Modeling, 6(1), 1-55. https://doi.org/10.1080/10705519909540118

Iskandar, Z. (2012). Psikologi lingkungan: teori dan konsep. Refika Aditama.

Jaenudin, U., \& Marliani, R. (2017). Psikologi lingkungan. Pustaka Setia.

Kaiser, F. G., Oerke, B., \& Bogner, F. X. (2007). Behavior-based environmental attitude: development of an instrument for adolescents. Journal of Environmental Psychology, 27, 242-251. https://doi.org/10.1016/j.jenvp.2007.06.004

Linacre, J. M. (1999). Investigating rating scale category utility. Journal of Outcome Measurement, 3(2), 103-122.

Linacre, J. M. (2002). What do infit and outfit, mean-square and standardized mean? Rasch Measurement Transactions, 16(2), 878.

Linacre, J. M. (2010). Predicting responses from Rasch measures. Journal of Applied Measurement, 11(1), 1-10.

Mair, P. (2018). Modern psychometrics with R. Springer International Publishing AG.

Masters, G. N. (1982). A Rasch model for partial credit scoring. Psychometrika, 47(2), 149-174. https://doi.org/10.1007/BF02296272

Milfont, T. L. (2007). Psychology of environmental attitudes: A cross-cultural study of their content and structure. Unpublished doctoral dissertation, University of Auckland, New Zealand.

Milfont, T. L. (2012). The psychology of environmental attitudes: conceptual and empirical insights from New Zealand. Ecopsychology, 4(4), 269-276. https://doi. org/10.1089/eco.2012.0058

Milfont, T. L., \& Duckitt, J. (2010). The environmental attitudes inventory: A valid and reliable measure to assess the structure of environmental attitudes. Journal of Environmental Psychology, 30(1), 80-94. https://doi.org/10.1016/j.jenvp.2009.09.001

Milfont, T. L., Duckitt, J., \& Wagner, C. (2010). The higher-order structure of environmental attitudes: a cross-cultural examination. Revista Interamericana de Psicología, 44(2), 263-273.

Navarro, O., Olivos, P., \& Fleury-Bahi, G. (2017). "Connectedness to Nature Scale": validity and reliability in the French context. Frontiers in Psychology, 8, 2180. https://doi.org/10.3389/fpsyg.2017.02180

Ogunbode, C. A., Henn, L., \& Tausch, N. (2020). Context-appropriate environmental attitude measurement in Nigeria using the Campbell paradigm. Environmental, Development, and Sustainability, 22(3), 2141-2158. https://doi.org/10.1007/ s10668-018-0281-1 
Oskamp, S. (2000). A sustainable future for humanity? How can psychology help? American Psychologist, 55(5), 496-508. https://doi.org/10.1037/0003$\underline{066 \times .55 .5 .496}$

Parker, L., \& Prabawa-Sear, K. (2020). Environmental education in Indonesia: creating responsible citizens in the global south? Routledge.

Prasetyo, D. T., Djuwita, R., \& Ariyanto, A. (2018). Who is more related to the nature? A study from Indonesia. E3S Web of Conferences, 74, 08009.

Rahayu, W., Putra, M. D. K., Faturochman., Meiliasari., Sulaeman, E., \& Koul, R. B. (2021). Development and validation of Online Classroom Learning Environment Inventory (OCLEI): the case of Indonesia during the COVID-19 pandemic. Learning Environments Research, https://doi.org/10.1007/s10984-021-09352-3

Rasch, G. (1960). Probabilistic models for some intelligence and attainment tests. Danish Institute for Educational Research.

Resolute, P. (2016). Humanizing the non-human animal: the framing analysis of dogs' rights movement in Indonesia. MASYARAKAT: Jurnal Sosiologi, 21(2), 149-172. https://doi/org/10.7454/mjs.v21i2.5073

Rudig, W. (2001). Western european studies: environment. In N. J. Smelser \& P. B. Baltes (Eds.), International encyclopedia of the social \& behavioral sciences (pp. 16463-16467). Pergamon.

Sarwono, S. W. (1992). Psikologi lingkungan. Grasindo.

Schultz, P. W., Shriver, C., Tabanico, J. J., \& Khazian, A. M. (2004). Implicit connections with nature. Journal of Environmental Psychology, 24(1), 31-42. https://doi. org/10.1016/S0272-4944(03)00022-7

Stern, P. C. (2000). Psychology and the science of human-environment interactions. American Psychologist, 55(5), 523-530. https://doi.org/10.1037/0003$\underline{066 \times .55 .5 .523}$

Sudarmadi, S., Suzuki, S., Kawada, T., Netti, H., Soemantri, S., \& Tugaswati, A. T. (2001). A survey of perception, knowledge, awareness, and attitude in regard to environmental problems in a sample of two different social groups in Jakarta, Indonesia. Environment, Development and Sustainability, 3, 169-183. https://doi. org/10.1023/A:1011633729185

Sugandini, D., Rahmawati, I., \& Arundati, R. (2018). Environmental attitude on the adoption decision mangrove conservation: An empirical study on communities in Special Region of Yogyakarta, Indonesia. Review of Integrative Business and Economic Research, 7(1), 266-175.

Suryadi, B., Hayat, B., \& Putra, M. D. K. (2020). Evaluating psychometric properties of the Muslim Daily Religiosity Assessment Scale (MUDRAS) in Indonesian samples using the Rasch model. Mental Health, Religion \& Culture, 23(3-4), 331-346. https://doi.org/10.1080/13674676.2020.1795822

Syarif Hidayatullah State Islamic University. (2020, January 17). Bertekad mewujudkan kampus ramah lingkungan, rektor UIN Jakarta minta stop penggunaan plastik. http://psikologi.uinjkt.ac.id/bertekad-mewujudkan-kampus-ramah-lingkungan-rektor-uin-jakarta-minta-stop-penggunaan-plastik/

Tiyarattanachai, R., \& Hollmann, N. M. (2016). Green Campus initiative and its impacts on quality of life of stakeholders in Green and Non-Green Campus universities. SpringerPlus, 5: 84. https://doi.org/10.1186/s40064-016-1697-4

University Leaders for a Sustainable Future (ULSF). (1990). Talloires declaration. http://ulsf.org/talloires-declaration/

University of Indonesia. (2016, September 22). Sustainability at Universitas Indonesia. http://green.ui.ac.id/about/

VandenBos, G. R. (2015). APA dictionary of psychology (2nd ed.). American Psychological Association. 
Wang, Y-C., \& Chiou, S-C. (2018). An analysis of the sustainable development of environmental education provided by museums. Sustainability, 10(11), 4054-4067. https://doi.org/10.3390/su10114054

Wang, J. \& Wang, X. (2020). Structural equation modeling: applications using Mplus (2nd ed.). John Wiley \& Sons Ltd.

Warm, T. A. (1989). Weighted likelihood estimation of ability in item response theory. Psychometrika, 54(3), 427-450. https://doi.org/10.1007/BF02294627

Wilson, M., \& Draney, K. (2002). A technique for setting standards and maintaining them over time. In S. Nishisato, Y. Baba, H. Bozdogan, \& K. Kanefugi (Eds.), Measurement and multivariate analysis (pp. 325-332). Springer-Verlag.

Wright, B. D., \& Masters, G. N. (1982). Rating scale analysis. MESA Press.

Wright, B. D., \& Stone, M. H. (1979). Best test design. MESA Press. 
Appendix A. Full item wording of Environmental Attitudes Measure

\begin{tabular}{|c|c|c|}
\hline Item & Original version & Indonesian version \\
\hline 1 & $\begin{array}{l}\text { I have a deep feeling of connectedness to } \\
\text { nature }\end{array}$ & Saya memiliki keterikatan yang erat dengan alam \\
\hline 2 & I don't feel a personal bond with nature & Saya tidak merasakan keterikatan pribadi dengan alam \\
\hline 3 & It hurts me to see nature being destroyed & Saya merasa tersakiti ketika melihat alam dirusak \\
\hline 4 & $\begin{array}{l}\text { I find it valuable to plant a tree at least one } \\
\text { time in my life }\end{array}$ & $\begin{array}{l}\text { Bagi saya, menanam pohon setidaknya satu kali dalam } \\
\text { hidup saya merupakan hal yang berharga }\end{array}$ \\
\hline 5 & $\begin{array}{l}\text { Things that I enjoy, but are bad for the } \\
\text { environment, I want to keep on doing }\end{array}$ & $\begin{array}{l}\text { Saya akan tetap melakukan hal-hal yang saya sukai } \\
\text { meskipun hal tersebut berdampak buruk pada } \\
\text { lingkungan }\end{array}$ \\
\hline 6 & $\begin{array}{l}\text { I like making an effort to contribute to a } \\
\text { better environment }\end{array}$ & $\begin{array}{l}\text { Saya senang ketika dapat berusaha untuk berkontribusi } \\
\text { untuk lingkungan yang lebih baik }\end{array}$ \\
\hline 7 & $\begin{array}{l}\text { I aspire a conscious and more natural } \\
\text { lifestyle }\end{array}$ & $\begin{array}{l}\text { Saya menginginkan gaya hidup yang penuh kepedulian } \\
\text { dan dekat dengan alam }\end{array}$ \\
\hline 8 & $\begin{array}{l}\text { I don't care so much that species are } \\
\text { becoming extinct }\end{array}$ & $\begin{array}{l}\text { Saya tidak peduli ketika mengetahui banyak spesies yang } \\
\text { akan punah }\end{array}$ \\
\hline 9 & $\begin{array}{l}\text { The relationship between human being } \\
\text { and nature should be one of respect, } \\
\text { adjustment and attunement }\end{array}$ & $\begin{array}{l}\text { Hubungan antara manusia dan alam haruslah saling } \\
\text { menghargai, saling menyesuaikan, dan harmonis }\end{array}$ \\
\hline 10 & $\begin{array}{l}\text { For solving environmental problems, } \\
\text { the government needs to get space for } \\
\text { carrying through strict rules and laws }\end{array}$ & $\begin{array}{l}\text { Untuk memecahkan masalah lingkungan, pemerintah } \\
\text { perlu memperoleh kesempatan untuk melaksanakan } \\
\text { peraturan dan hukum secara tegas }\end{array}$ \\
\hline 11 & $\begin{array}{l}\text { Every individual needs to contribute to } \\
\text { solving the climate problem }\end{array}$ & $\begin{array}{l}\text { Setiap orang perlu untuk berkontribusi dalam mengatasi } \\
\text { permasalahan lingkungan }\end{array}$ \\
\hline 12 & $\begin{array}{l}\text { What is good for the environment, is in the } \\
\text { end also good for the economy }\end{array}$ & $\begin{array}{l}\text { Hal yang baik untuk lingkungan pada akhirnya juga akan } \\
\text { berdampak baik bagi ekonomi }\end{array}$ \\
\hline 13 & $\begin{array}{l}\text { It gives me a good feeling to buy products } \\
\text { that contribute to a better environment, } \\
\text { even when they are a bit more expensive }\end{array}$ & $\begin{array}{l}\text { Tidak masalah bagi saya untuk membeli produk yang } \\
\text { agak mahal namun berdampak kepada lingkungan yang } \\
\text { lebih baik. }\end{array}$ \\
\hline 14 & $\begin{array}{l}\text { For solving the climate problem we need to } \\
\text { adjust our lifestyle }\end{array}$ & $\begin{array}{l}\text { Untuk dapat memecahkan permasalahan lingkungan, } \\
\text { manusia harus menyesuaikan gaya hidupnya }\end{array}$ \\
\hline 15 & $\begin{array}{l}\text { Changing my own behavior will hardly } \\
\text { contribute to solving environmental } \\
\text { problems }\end{array}$ & $\begin{array}{l}\text { Merubah perilaku saya sendiri tidak cukup kuat untuk } \\
\text { berkontribusi dalam menyelesaikan permasalahan } \\
\text { lingkungan }\end{array}$ \\
\hline 16 & $\begin{array}{l}\text { Nature has value only because the human } \\
\text { being is able to use and enjoy her }\end{array}$ & $\begin{array}{l}\text { Alam merupakan sesuatu yang berharga hanya jika } \\
\text { manusia dapat menggunakan dan menikmatinya }\end{array}$ \\
\hline 17 & $\begin{array}{l}\text { By mastering nature, the human being can } \\
\text { find freedom }\end{array}$ & $\begin{array}{l}\text { Dengan menguasai alam, manusia akan menemukan } \\
\text { kebebasan bertindak. }\end{array}$ \\
\hline 18 & $\begin{array}{l}\text { Environmental problems will be solved } \\
\text { through the working of the market, for } \\
\text { example because oil prices are going up }\end{array}$ & $\begin{array}{l}\text { Permasalahan lingkungan akan teratasi dengan } \\
\text { berlakunya hukum pasar (ekonomi), misalnya ketika } \\
\text { harga bahan bakar naik }\end{array}$ \\
\hline 19 & $\begin{array}{l}\text { Through the development of science and } \\
\text { technology, environmental problems will be } \\
\text { solved by itself }\end{array}$ & $\begin{array}{l}\text { Dengan perkembangan sains dan teknologi, } \\
\text { permasalahan lingkungan akan selesai dengan } \\
\text { sendirinya }\end{array}$ \\
\hline 20 & $\begin{array}{l}\text { In these economically difficult times, } \\
\text { environmental requirements should not } \\
\text { become obstacles to economic growth }\end{array}$ & $\begin{array}{l}\text { Dalam situasi ekonomi yang serba sulit seperti saat ini, } \\
\text { hal-hal terkait lingkungan jangan menjadi penghalang } \\
\text { untuk pertumbuhan ekonomi }\end{array}$ \\
\hline 21 & I think animal rights are nonsense & $\begin{array}{l}\text { Saya merasa bahwa hak-hak yang dimiliki binatang } \\
\text { bukanlah hal yang masuk akal }\end{array}$ \\
\hline 22 & $\begin{array}{l}\text { I don't feel responsible for contributing to } \\
\text { solving the enviromental crisis }\end{array}$ & $\begin{array}{l}\text { Saya tidak merasa bertanggung jawab untuk } \\
\text { berkontribusi dalam mengatasi permasalahan } \\
\text { lingkungan }\end{array}$ \\
\hline
\end{tabular}

